2. Панова Л. С., Андрійко І. Ф. Методика навчання іноземних мов у загальноосвітніх навчальних закладах. Київ: Академія, 2010. 327 с.

3. Ніколаєва С. Ю. Методика викладання іноземних мов у середніх навчальних закладах. Київ: Ленвіт, 2002. 328 с.

4. Пінчук I. О. Англомовна компетентність як складник професійної підготовки майбутніх учителів початкових класів. Young Scientist. 2014. № 12. С. 177-180.

DOI https://doi.org/10.30525/978-9934-26-114-5-58

\title{
ЗАСОБИ ЕЛЕКТРОННОЇ ДИДАКТИКИ В МОВНІЙ ПІДГОТОВЦІ ЗДОБУВАЧІВ ВИЩОЇ ОСВІТИ
}

\author{
Нагрибельна I. А. \\ докторка педагогічних наук, \\ професорка кафедри соиіально-гуманітарних дисииплін \\ та інноваиійної педагогіки \\ Херсонська державна морська академія \\ Нагрибельний Б. Я. \\ учитель історії та права НВК № 9 I-III cm. навчання \\ м. Херсон, Украӥна
}

Процес активної модернізація системи вищої освіти в Україні зумовлений низкою чинників. Серед провідних відзначимо такі: соціальний запит на конкурентного випускника вишу; потреба увідповіднення змісту та методів навчання; розширення спектру альтернативних джерел інформації для здобувачів вищої освіти; потреба в розвитку та удосконаленні цифрової грамотності усіх учасників освітнього процесу.

У системі вищої освіти пріоритет означених чинників зумовив оновлення мовної підготовки сучасних здобувачів. Тенденції мовномовленнєвої освіти у виші демонструють виокремлення категорій електронної дидактики та їх активне застосування в освітньому процесі. Так, наприклад, в мовній підготовці здобувачів вищої освіти Херсонської державної морської академії ефективно використовуються засоби цифровізації.

Сучасний арсенал цифрових засобів навчання постійно розширюється та удосконалюється, тому для вибору доцільних саме в мовній освіті маємо оцінити функціонал основних ресурсів. Погоджуємося із 
узагальненням та твердженням про те, що «...свою практичну значущість та ефективність активно доводять цифрові інструменти, що використовуються в освітньому просторі: Zoom, Skype, Webex, Google Meet, Classtime, Moodle, Learning Apps, Canva, Genially, Storyboardthat» [3,c.152]. Водночас зауважимо, що не всі вони можуть бути ефективно використані саме для формування мовно-мовленнєвої особистості здобувача вищої освіти з огляду на своє функціональне призначення. Наприклад, сервіси Webex, GoogleMeet, Zoom, Skype можуть бути використані для активної комунікації учасників освітнього процесу в режимі реального часу. Успішно впроваджуються в процес мовної освіти сервіси для організації інтерактивної діяльності учасників освітнього процесу. До них відносимо такі: Moodle, LearningApps, Classtime. Своєю чергою такі додатки для розвитку цифрової творчості, як Canva, Genially, Storyboardthat, в мовній освіті не мають пріоритетної ролі.

Студіювання проблеми цифрових засобів в мовній освіті вищої школи загалом та їх аналіз як окремої категорії електронної дидактики, власний викладацький досвід дозволяють виокремити 3-поміж інших ресурсів LMS MOODLE (Modular Object-Oriented Dynamic Learning Environment).

Означена освітня платформа застосовується в практиці вишів. Влучно іiі роль в мовній освіті здобувачів - майбутніх фахівців морської галузі ілюструє наступна теза-характеристика : «...привабливість виявляється не тільки в інтуїтивно зрозумілій системі (навіть не для спеціалістів) інструментів для впровадження комп'ютерного навчання та в докладних інструкціях щодо їх застосування, а й у пристосованості до сучасних освітніх потреб. Так, можливості інформаційного середовища MOODLE дозволяють ефективно організовувати взаємодію викладача й студента в умовах дистанційного навчання за допомогою форуму, чату, розвиненої системи коментування й оцінювання теоретичних та практичних завдань, а інструменти автоматичної перевірки суттєво економлять час викладача та звільняють від рутинної роботи. Відкритість його форми дає можливість додавати нові модулі й блоки, а також постійно удосконалювати навчальний матеріал» [4]. Нам імпонує таке твердження, оскільки воно демонструє сильні сторони означеного ресурсу та лаконічно передає розлогі можливості інформаційного середовища MOODLE в мовній освіті здобувачів вищої освіти.

Окремої уваги, як нам видається, заслуговує той факт, що цей цифровий засіб не тільки не обмежує можливості для формування комунікативної компетентності студентів (курсантів), а й створює нові 
можливості для іiї удосконалення. Наприклад, обмеження, що пов'язані зі специфікою дистанційного навчання [5] підтверджують ефективність pecyрсу LMS MOODLE під час вивчення курсів «Українська мова (за професійним спрямуванням)», «Сучасне наукове мовлення».

Аналізуючи освітні можливості ресурсу наведемо приклади практичних завдань, що передбачають розвиток професійної лексики, удосконалення комунікативної компетентності та закріплення цифрової грамотності майбутніх фахівців морської галузі засобом навчання на базі інформаційного середовища MOODLE у веб-системі Херсонської державної морської академії (LMS MOODLE KSMA). У межах розробленого контенту курсу «Українська мова (за професійним спрямуванням)» на платформі представлено такі завдання:

1. Поясніть лексичне значення поданих слів. Обтрунтуйте їx приналежність до професійної лексики.

2. Укладіть речення зі словами (на вибір) та поясніть правопис їх.

3. Завантажте файл із відповідями на платформу LMS MOODLE KSMA.

Лексика для опрацювання: мушкель, морехідна астрономія, мол, гюйс, грот-щогли, ворса, водотонажність, вогні судові, вітрильне оснащення, приспуститися, прокладка, лавірувати. курсограф, мідель.

Ефективним прикладом застосування засобів електронної дидактики вважаємо елементи доповненої реальності та симуляції. Безперечно, не всі вони однаково доцільні та методично ефективні в мовній (україномовній) освіті здобувачів-носіїв мови. Проте їх роль в навчанні іноземних студентів $\epsilon$ актуальною та перспективною. Адже оволодіння українською фаховою лексикою засобами доповненої реальності створює для іноземних студентів якісні можливості для розуміння, опанування та активного застосування іiї.

У науковій літературі описано перспективний освітній досвід, що реалізується в ХДМА. В освітніх часописах міститься така інформація: «... ефективно працює сучасний тренажерний комплекс «Віртуальнореальне судно», який дозволяє моделювати означені та інші професійні комунікативні ситуації в умовах наближених до реальності.» [2, с. 219]. Засобом такого комплексу доповненої реальності можливе створення професійно-виробничих ситуацій в умовах, що наближені до реальності. Моделювання подібних ситуацій ефективне не тільки для набуття фахової компетентності майбутніми моряками, а й для розвитку їх мовно-мовленнєвої грамотності. В таких умовах, що «...моделюється на віртуальних тренажерах «Повфнофункціональний навігаційний місток» та на тренажері «Машинне відділення»... передбачено комунікацію, що полягає в наданні команд з судового 228 
містка про певні дії судновому вахтовому механіку. Логіка дій останнього підкріплюється доцільними командами, які пов'язані 3 рухом та логістикою судна» [2, с. 219]. Отже, імітація фахових ситуацій засобом віртуальної реальності сприяе доцільному та грамотному застосуванню професійної лексики, комунікації в команді, міжкультурній комунікації.

Аналіз порушеної проблеми дозволяє стверджувати, що тенденції вищої освіти демонструють виокремлення нових категорій дидактики, які ми визначаємо як засоби електронної дидактики. Вони уособлюють в собі потенційні можливості для розвитку мовної освіти та формують цифрову грамотність здобувачів. Така інтеграція створює ефективну освітню площину для мовної освіти сучасних здобувачів закладів вищої освіти.

\section{Література:}

1. Blended English: Technology-enhanced teaching and learning in English literary studies / N. Milthorpe, R. Clarke, L. Fletcher, R. Moore, H. Stark та ін. Arts and Humanities in Higher Education. 2018. N 17. C. 345-365.

2. Нагрибельна I. Методика формування комунікативної компетентності майбутніх фахівців морської галузі в системі вищої освіти. Актуальні питання гуманітарних наук. -Дрогобич: Видавничий дім «Гельветика», 2020. - Вип. 34. Том 4. С. 219.

3. Нагрибельна I.А. Навчання української мови майбутніх фахівців морської галузі засобами цифровізації. Збірник наукових праць «Педагогічні науки»№ 94. 2020. С. 152.

4. Нагрибельна, І. А., Сугейко, Л. Г., Мельничук, Ю. Ю. Упровадження дистанційного курсу з методики навчання української мови на основі системи MOODLE. Інформаційні технології і засоби навчання, 2020, 77(3), 162-174. https://doi.org/10.33407/itlt.v77i3.2759 https://doi.org/10.33407/itlt.v77i3.2759 REFERENCES.

5. Положення про дистанційне навчання. URL: https://zakon.rada.gov.ua/laws/show/z0703-13 \#Text (date of access: 24.02.2021). 